ARTICLE

Received 28 May 2014 | Accepted 4 Nov 2014 | Published 17 Dec $2014 \quad$ DOl: 10.1038/ncomms6754

\title{
A unifying model for Neoproterozoic-Palaeozoic exceptional fossil preservation through pyritization and carbonaceous compression
}

James D. Schiffbauer ${ }^{1}$, Shuhai Xiao ${ }^{2}$, Yaoping $\mathrm{Cai}^{3}$, Adam F. Wallace ${ }^{4}$, Hong Hua $^{3}$, Jerry Hunter ${ }^{5}$, Huifang Xu' Yongbo Peng ${ }^{7} \&$ Alan J. Kaufman ${ }^{8}$

Soft-tissue fossils capture exquisite biological detail and provide our clearest views onto the rise of animals across the Ediacaran-Cambrian transition. The processes contributing to fossilization of soft tissues, however, have long been a subject of debate. The Ediacaran Gaojiashan biota displays soft-tissue preservational styles ranging from pervasive pyritization to carbonaceous compression, and thus provides an excellent opportunity to dissect the relationships between these taphonomic pathways. Here geochemical analyses of the Gaojiashan fossil Conotubus hemiannulatus show that pyrite precipitation was fuelled by the degradation of labile tissues through bacterial sulfate reduction (BSR). Pyritization initiated with nucleation on recalcitrant tube walls, proceeded centripetally, decelerated with exhaustion of labile tissues and possibly continued beneath the BSR zone. We propose that pyritization and kerogenization are regulated principally by placement and duration of the decaying organism in different microbial zones of the sediment column, which hinge on post-burial sedimentation rate and/or microbial zone thickness.

\footnotetext{
${ }^{1}$ Department of Geological Sciences, University of Missouri, Columbia, Missouri 65211, USA. ${ }^{2}$ Department of Geosciences, Virginia Tech, Blacksburg, Virginia 24061, USA. ${ }^{3}$ Early Life Institute, State Key Laboratory of Continental Dynamics, and Department of Geology, Northwest University, Xi'an 710069, China.

${ }^{4}$ Department of Geological Sciences, University of Delaware, Newark, Delaware 19716, USA. ${ }^{5}$ Nanoscale Characterization and Fabrication Laboratory, Institute of Critical Technology and Applied Science, Virginia Tech, Blacksburg, Virginia 24061, USA. ${ }^{6}$ NASA Astrobiology Institute, Department of Geoscience, University of Wisconsin, Madison, Wisconsin 53706, USA. ${ }^{7}$ Department of Geological Sciences, Indiana University, Bloomington, Indiana 47405, USA. ${ }^{8}$ Department of Geology and Earth System Science Interdisciplinary Center, University of Maryland, College Park, Maryland 20742, USA. Correspondence and requests for materials should be addressed to J.D.S. (email: schiffbauerj@missouri.edu).
} 
S oft-tissue fossils in the geological record are rare relative to the profusion of shelly hard parts. While shelly organisms produce mineralized structures in vivo, soft tissues require authigenic mineralization to enter the fossil record. The factors contributing to soft-tissue mineralization can be partitioned into two distinct but complementary categories: those that facilitate and those that drive preservation. Facilitating factors are typically palaeoenvironmental in nature, serving to chemically or mechanically delay or inhibit aggressive aerobic degradation (noted in ref. 1 as 'distal environmental and diagenetic conditions'). While independently invoked as responsible for soft-tissue preservation, facilitating factors are neither mutually exclusive nor sufficient to guarantee fossilization. These conditions can only enable soft-tissue preservation, because delaying degradation is only part of the preservational puzzle. Driving factors refer to constructive mineralization processes that replicate or stabilize soft tissues ('proximal causes' of ref. 1), ensuring their survivability through geological time and diagenetic alteration. Counterintuitively, many mineralization processes are dependent on microbially mediated degradation to

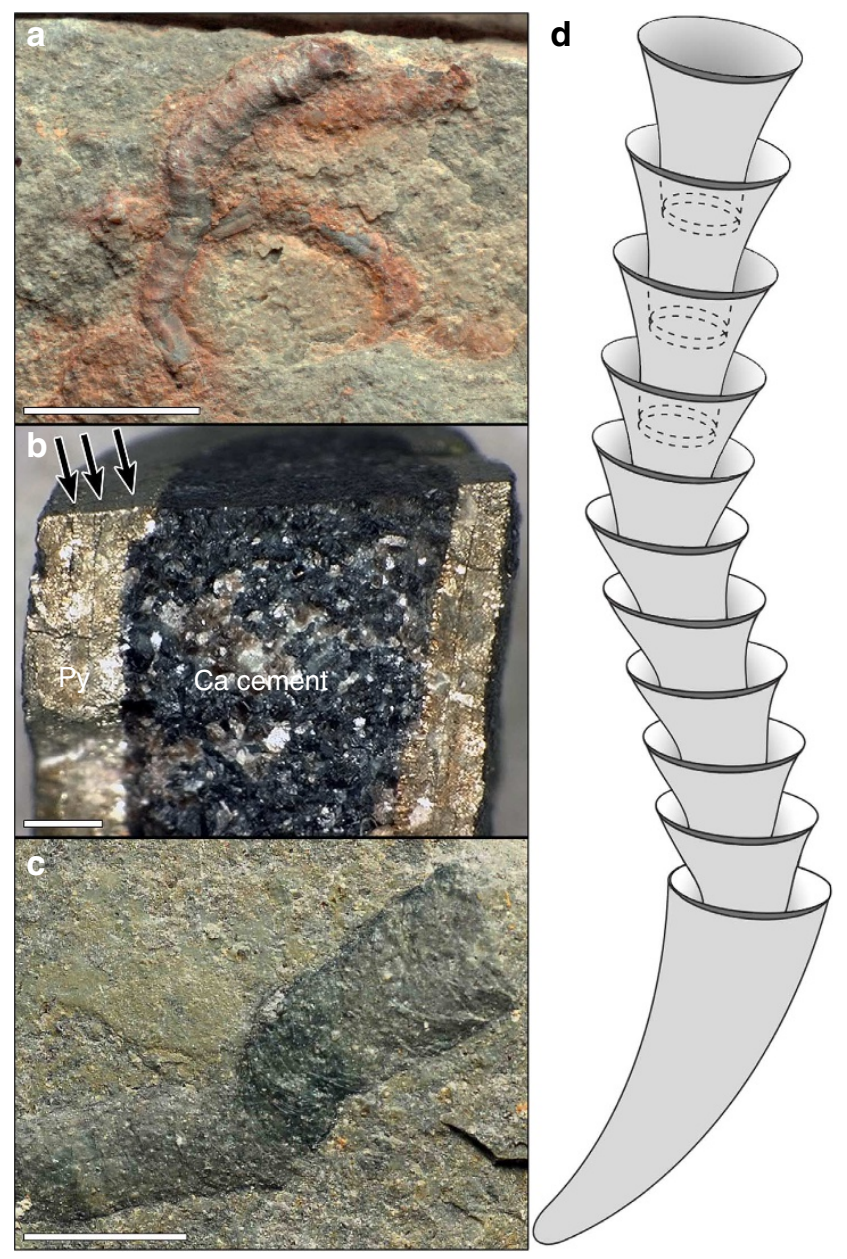

Figure 1 | Taphonomic representations of Conotubus hemiannulatus.

(a) Pervasively pyritized (rusty weathered colour) Conotubus on bedding plane. Scale bar, $5 \mathrm{~mm}$. (b) Longitudinally fractured Conotubus specimen showing carbonate cement infill (labelled Ca cement), with pyritized (labelled Py) nested funnel walls visible (arrows). Scale bar, $1 \mathrm{~mm}$ (c) Specimen of Conotubus preserved as two-dimensional carbonaceous compressions with aluminosilicate coating. Scale bar, $5 \mathrm{~mm}$. (d) Interpretive schematic of Conotubus showing flexible, funnel-in-funnel tube structure and morphology. Figures in b,c are reproduced with permission from Elsevier (modified from ref. 28 and ref. 1, respectively). provide and locally concentrate necessary chemical constituents. Each case of soft-tissue preservation is thus a race between destructive decay and constructive mineralization processes ${ }^{2}$. Superlative fossils occur in a narrow window where neither degradation obliterates nor mineralization overprints important biological details, a scenario contingent on both appropriate settings and rapid stabilization processes.

Spanning across the Ediacaran-Cambrian transition, when Konservat-Lagerstätten (deposits with exceptional soft-tissue preservation $^{3}$ ) are most abundant ${ }^{4,5}$, numerous mineralization pathways fulfil the role of soft-tissue stabilizers ${ }^{6,7}$. Two of these pathways-Beecher's Trilobite-type pyritization (threedimensional pervasive pyritization) and Burgess Shale-type kerogenization (two-dimensional carbonaceous compression)are particularly important. Pervasive pyritization is commonly facilitated by rapid burial, minimal ambient organic material, periodic or persistent anoxia/dysoxia, reactive iron and sulfate availability, low bioturbation and bacterial sulfate reduction (BSR)-mediated decay ${ }^{1,8-14}$ (BSR: $\mathrm{CH}_{3} \mathrm{COO}^{-}+\mathrm{SO}_{4}^{2-} \rightarrow 2$ $\mathrm{HCO}_{3}^{-}+\mathrm{HS}^{-}$). By and large, kerogenization has been attributed to many of the same facilitating conditions, mostly related to rapid burial into anoxic/dysoxic palaeoenvironments ${ }^{15}$. While numerous other palaeoenvironmental and diagenetic considerations have been invoked for kerogenization, such as interactions with clays ${ }^{6,16}$ or ferrous iron ${ }^{17}$, high alkalinity ${ }^{15,18}$ and oxidant restriction (that is, lack of sulfate for BSR) through early diagenetic sealing ${ }^{18}$ (though see also ref. 19), the common association of kerogenized fossils with pyrite $1,6,12,16,20-24$ bolsters the interrelationship of these taphonomic processes.

Fossils in the late Ediacaran ( 551-541 Ma) Gaojiashan Lagerstätte illustrate a preservational gradient from pervasive pyritization to compressed kerogenization ${ }^{1}$, including threedimensional pervasive pyritization, incomplete pyritization and carbonaceous compression with associated pyritization. As such, this Lagerstätte offers an opportunity to establish a comprehensive taphonomic model marrying these pathways. To this end, we geochemically investigate the abundant Gaojiashan fossil Conotubus hemiannulatus, which shows preservation in each of these taphonomic styles. Our data form the basis for the proposed unifying model, which invokes sedimentation rate, and thus time the decaying carcass spends in specific microbial zones, to regulate taphonomic styles along the pyritization-kerogenization gradient.

\section{Results}

General taphonomic observations. Among hundreds of Conotubus specimens examined in this study, $\sim 80 \%$ are preserved three-dimensionally through complete or incomplete pyritization (Fig. 1a,b), with the remaining preserved through two-dimensional kerogenization ${ }^{1}$ (Fig. 1c). Pervasively pyritized Conotubus specimens possess secondary cracks filled with calcite cements, and thin rinds $(<20 \mu \mathrm{m})$ of iron oxide along these cracks (Figs 2g,3c and 4e). Viewed in longitudinal and transverse crosssections (Figs $2 \mathrm{a}, 3 \mathrm{a}$ and $4 \mathrm{~b}$ ), these specimens show a bimodal size distribution of pyrite crystals. Generally, a micrometric size class of crystals ranges from $\sim 10$ to $\sim 250 \mu \mathrm{m}$, and a millimetric size class of crystals ranges from $\sim 800 \mu \mathrm{m}$ to a few $\mathrm{mm}$. Micrometric pyrite crystals are mainly found at the outer edge of the fossil (Figs $2 \mathrm{a}$ and $3 \mathrm{a}$ ) and sometimes along non-continuous central voids (Fig. 3a) or fractures (Figs $2 \mathrm{a}$ and $4 \mathrm{~b}$ ), whereas millimetric pyrite crystals comprise the bulk of the tube interior (Fig. 2a). In some cases, millimetric crystals appear to be amalgamations of micrometric crystals (Fig. 3a). In others, millimetric crystals appear to have subtle textural variations along their outer edges, possibly indicative of later overgrowth (Fig. $2 \mathrm{~b}, \mathrm{c}$ ). 


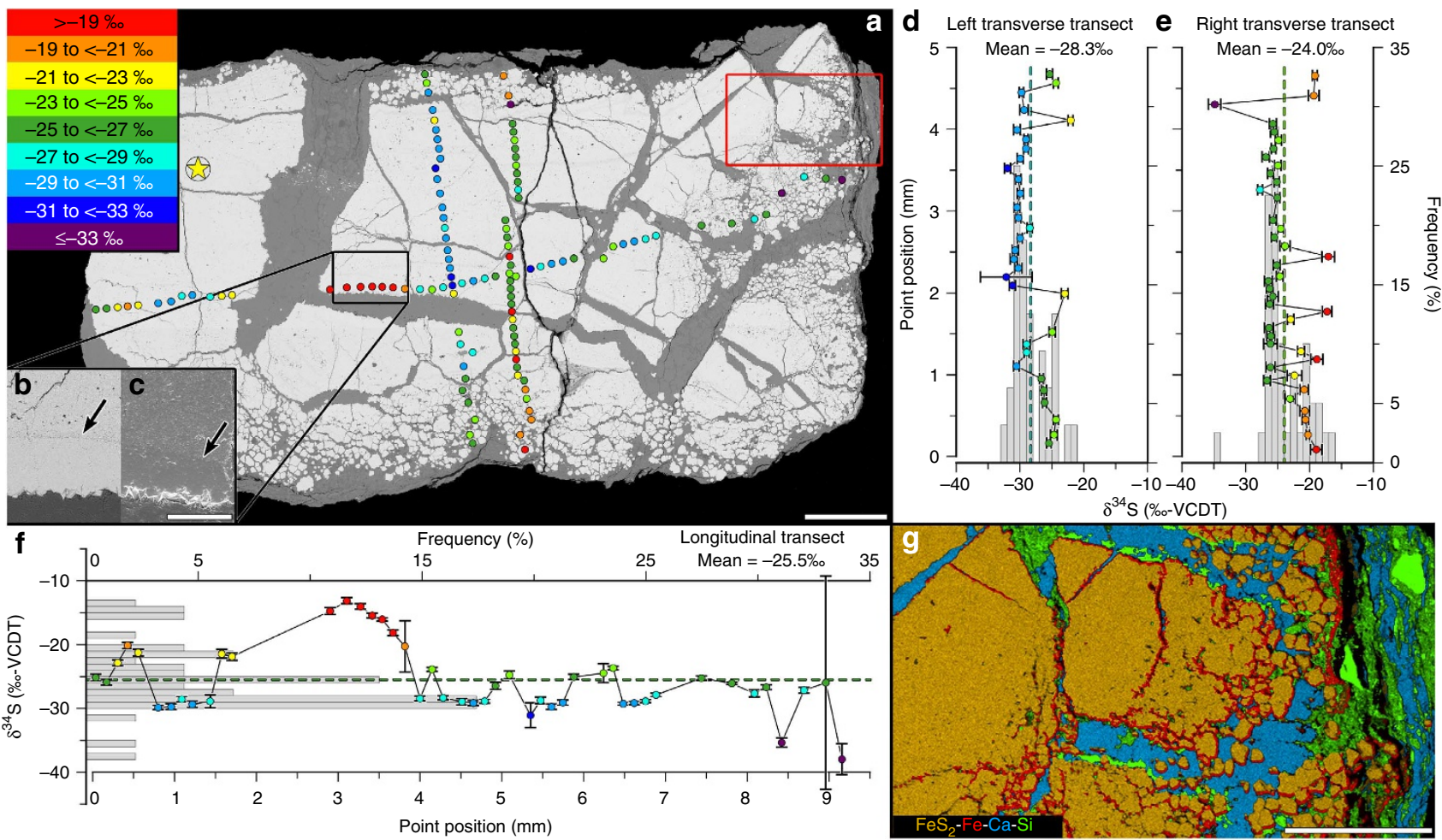

Figure 2 | SEM/EDS and SIMS $\boldsymbol{\delta}^{\mathbf{3 4}} \mathbf{S}_{\mathbf{P Y}}$ data for Conotubus specimen GJS-Cono001. (a) Backscatter Z-contrast electron micrograph montage of longitudinal section, with all SIMS spots (circles) plotted at analysis location. Microdrilling location for IRMS $\delta^{34} S_{\text {PY }}$ assessment indicated by star. Point and star colour corresponds to $\delta^{34} S_{\text {PY }}$ bins shown in upper left key. Scale bar, $1 \mathrm{~mm}$. Insets (b,c) at lower left show higher magnification split-frame of black rectangle region highlighting subtle textural difference associated with pyrite overgrowth (arrows in each panel); backscatter electron (b) and secondary electron (c) images. Scale bar, $250 \mu \mathrm{m}$. (d-f) SIMS transects, with dashed lines indicating mean values and histograms showing frequency of points by $1 \%$ bins. Note generalized U-shaped profile in $\mathbf{d}$ (left transect), with higher values towards fossil edges and lower values centrally located. To show precision of each 10-cycle point sample mean, error bars mark \pm 1 standard error. These errors do not include the analytical uncertainties of the Balmat pyrite standard, which are relatively small. (g) Energy-dispersive X-ray elemental overlay of iron-sulfur (gold), iron but no sulfur (red), calcium (blue) and silicon (green). Map region corresponds to red rectangle in a. Scale bar, $500 \mu \mathrm{m}$.

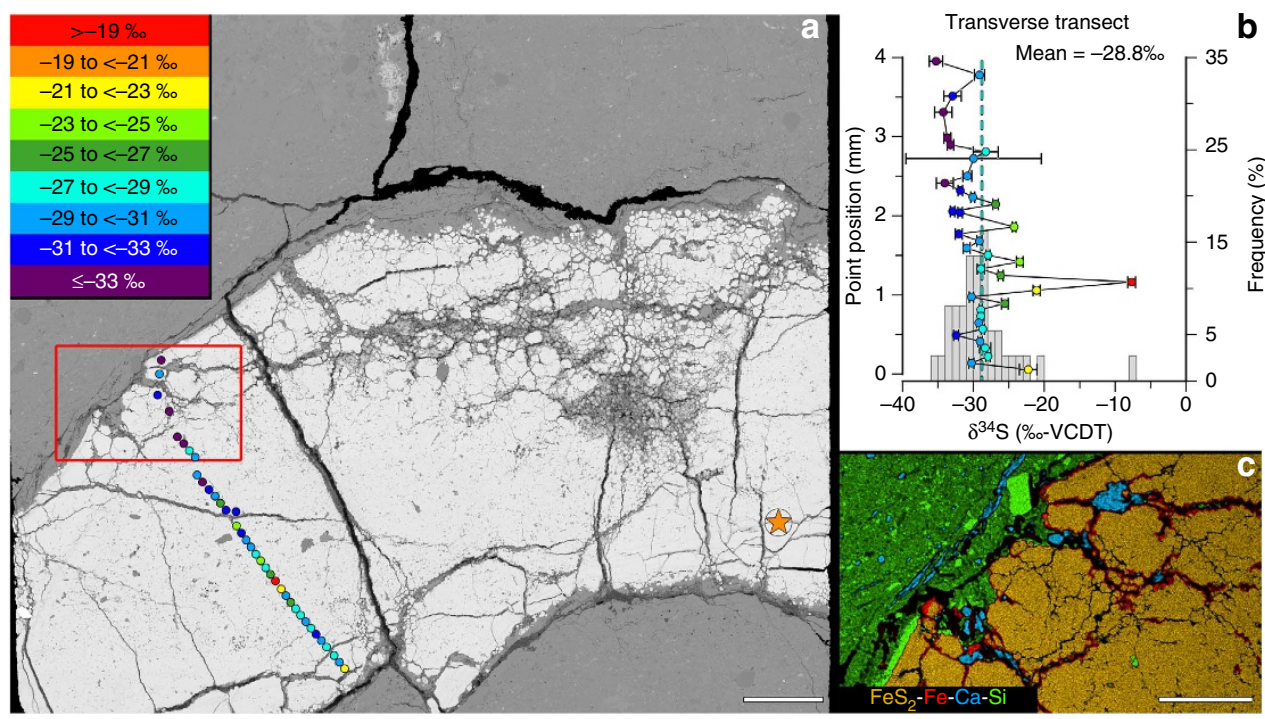

Figure 3 | SEM/EDS and SIMS $\delta^{\mathbf{3 4}} \mathbf{S}_{\mathrm{PY}}$ data for Conotubus specimen GJS-Cono002. (a) Backscatter Z-contrast electron micrograph montage of longitudinal section, with all SIMS spots (circles) plotted at analysis location. Microdrilling location for IRMS $\delta^{34} S_{\text {PY }}$ assessment indicated by star. Point and star colour corresponds to $\delta^{34} S_{P Y}$ bins shown in upper left key. Scale bar, $1 \mathrm{~mm}$. (b) SIMS transect, with dashed line indicating mean value, and histogram showing frequency of points by $1 \%$ bins. To show precision of each 10 -cycle point sample mean, error bars mark \pm 1 s.e. These errors do not include the analytical uncertainties of the Balmat pyrite standard, which are relatively small. (c) EDS elemental overlay of iron-sulfur (gold), iron but no sulfur (red), calcium (blue) and silicon (green). Map region corresponds to red rectangle in a. Scale bar, $500 \mu \mathrm{m}$. 

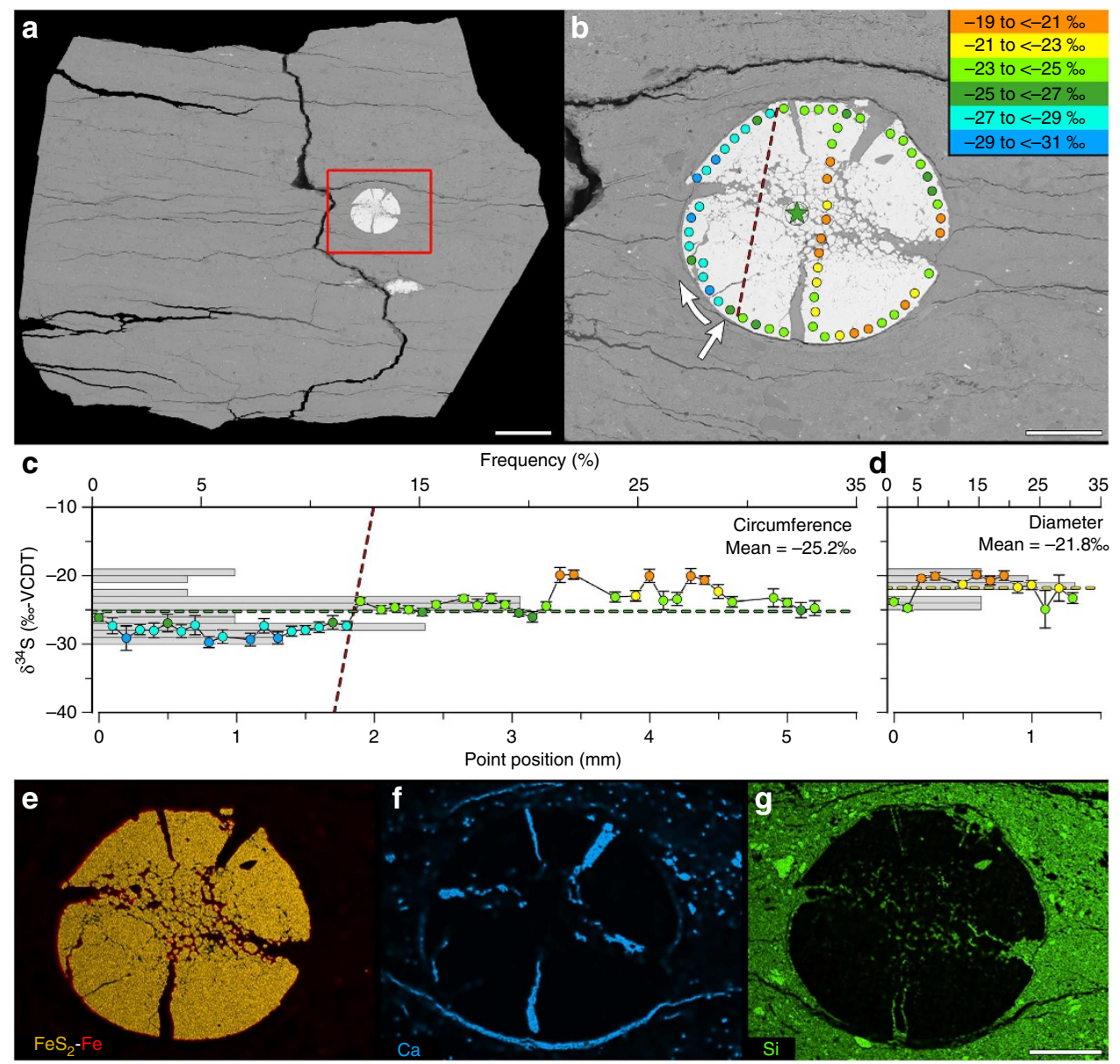

Figure 4 | SEM/EDS and $\boldsymbol{\delta}^{\mathbf{3 4}} \mathbf{S}_{\mathrm{PY}}$ data for Conotubus specimen GJS-Cono003. (a,b) Backscatter Z-contrast electron micrograph montage of transverse section, with all SIMS spots (circles) plotted at analysis location. Microdrilling for IRMS $\delta^{34} S_{\text {PY }}$ was made on the reverse side of the specimen at a location corresponding to the star. Point and star colour corresponds to $\delta^{34} S_{P Y}$ bins shown in upper right key. Scale bar in $\mathbf{a}, 2 \mathrm{~mm}$, in $\mathbf{b}, 500 \mu \mathrm{m}$. (c,d) $\mathrm{SIMS}$ circumference and diameter transects, respectively, with dashed lines indicating mean values, and histograms showing frequency of points by $1 \%$ bins. Circumference $\delta^{34} S_{P Y}$ plot follows clockwise from straight arrow in $\mathbf{b}$. Using dashed red line in $\mathbf{b}$ as a reference, note slight separation of $\delta^{34} S_{P Y}$ values: higher $\delta^{34} S_{P Y}$ values to the right and lower $\delta^{34} S_{P Y}$ values to the left of the dashed line in $\mathbf{b}$. Diameter $\delta^{34} S_{P Y}$ plot follows top-to-bottom. To show the precision of each 10 -cycle point sample mean, error bars mark \pm 1 s.e. These errors do not include the analytical uncertainties of the Balmat pyrite standard, which are relatively small. (e-g) EDS elemental overlay of iron-sulfur (gold), iron but no sulfur (red), calcium (blue) and silicon (green). Map region corresponds to red rectangle in $\mathbf{a}$. Scale bar in $\mathbf{g}$ is $500 \mu \mathrm{m}$, applicable for $\mathbf{e}$ and $\mathbf{f}$.

Sulfur isotopic data. Pyrite sulfur isotopic values $\left(\delta^{34} S_{\mathrm{PY}}\right)$, measured using secondary ion mass spectroscopy (SIMS), range between -7.6 and $-37.9 \%$-VCDT (Supplementary Table 1 and Fig. 2a,d-f; Fig. 3a,b; Fig. 4b-d). Although not a hard-and-fast rule, pyrite with $\delta^{34} S_{\mathrm{PY}}$ values $\geq-19 \%$ o tend to be associated with fractures and/or textural variations in the pyritized fossil, which may correspond to later overgrowth (for instance, see adjacent red points in Fig. 2a longitudinal transect positioned just below arrows indicating textural variation in Fig. $2 \mathrm{~b}, \mathrm{c}$ ). Disregarding obvious fracture-associated ${ }^{34} \mathrm{~S}$-enriched points, the transverse $\delta^{34} S_{\text {PY }}$ transects exhibit a generalized U-shaped profile, with localization of greater values along the tube-wall edges and lower values towards the center of the fossil (Fig. 2d,e). This pattern is not discernable in all specimens (Figs $3 \mathrm{~b}$ and $4 \mathrm{c}, \mathrm{d}$ ). Microdrilled pyrite assessed via isotope ratio mass spectroscopy (IRMS) yield $\delta^{34} S_{P Y}$ values broadly similar to mean SIMS values (Supplementary Table 1). Carbonate-associated sulfate sulfur isotopic composition $\left(\delta^{34} \mathrm{~S}_{\mathrm{CAS}}\right)$ of host rock was assessed at $+33.6 \%$-VCDT (Supplementary Table 1), comparable to contemporaneous units in Oman ${ }^{25}$. Thus, $\Delta^{34} S_{\text {CAS-PY }}$ is appreciably high (ranging from +41.2 to $71.5 \%$ ).
Carbon and oxygen isotopic data. Three-dimensionally but incompletely pyritized Conotubus specimens show an outer rim of pyrite, with multiple generations of compositionally distinct carbonate cements surrounding a central void in the tube interior (Fig. 5). In the only chemically analysed cross-section with this preservational style but representative of other similarly preserved specimens, the outer first generation cements consist of large centripetally terminating calcite crystals, indicating inward carbonate growth from the pyrite rim. The inner second generation cements are zoned rhombohedral crystals, with alternating ultraviolet-luminescent zones of ferroan dolomite and dull zones of dolomite + calcite. Carbon and oxygen isotopic compositions of microlaminae in the host rock and for the two generations of fossil carbonate cements were determined (Supplementary Table 2 and Fig. 6). The mean $\delta^{13} \mathrm{C}$ value of the darker coloured microlaminae $(6.1 \pm 0.9 \% \mathrm{VPDB})$ is greater than that of the lighter coloured microlaminae $(4.4 \pm 1.0 \%$ ) with slight overlap in ranges, whereas their mean $\delta^{18} \mathrm{O}$ values are broadly similar (darker microlaminae $=-5.4 \pm 1.2 \%$; lighter microlaminae $=$ $-5.9 \pm 0.3 \%$ ) with mostly overlapping ranges. While similar in carbon isotope composition, the cements in the Conotubus 


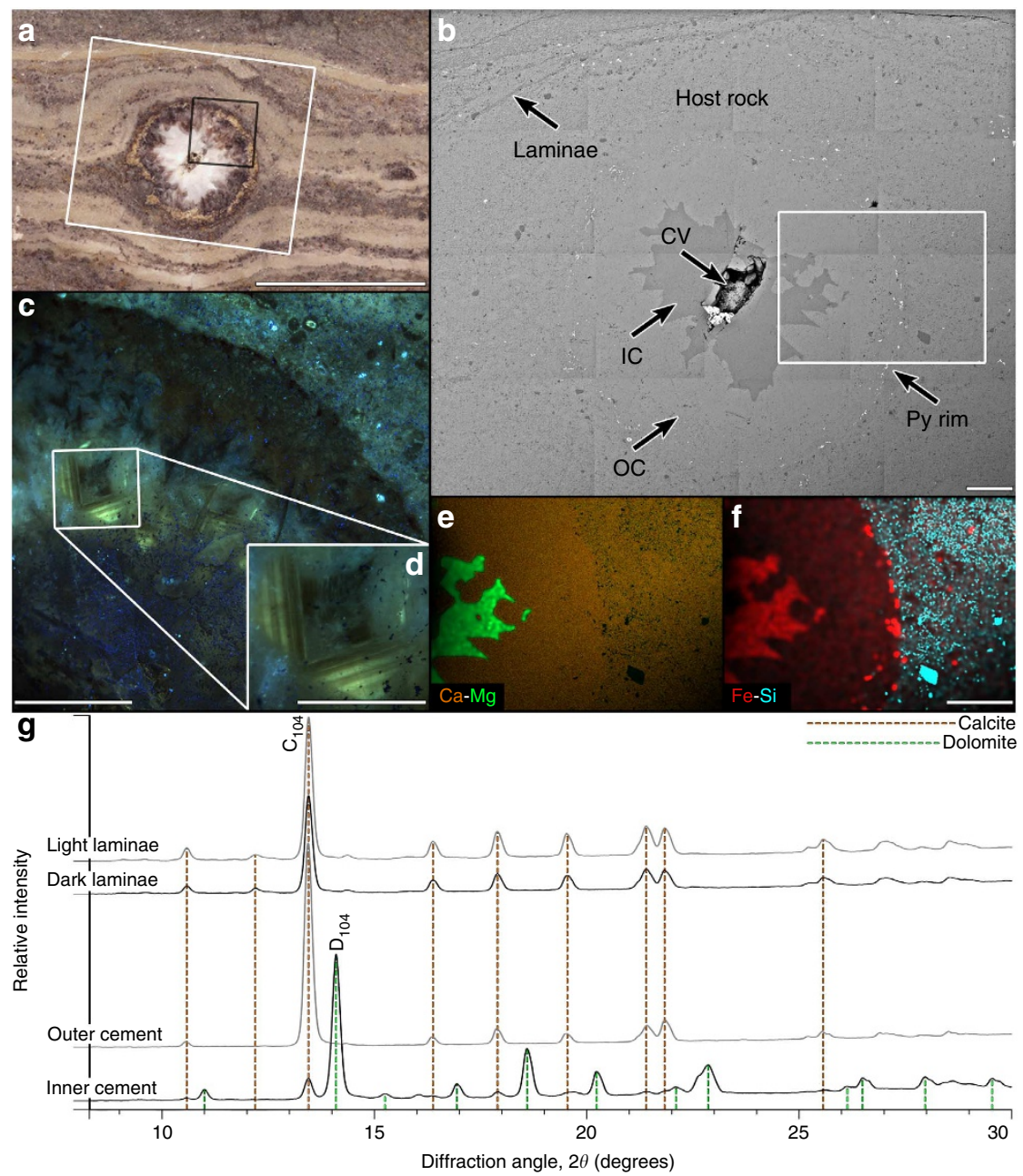

Figure 5 | Ultraviolet photoluminescence and in situ XRD data for Conotubus specimen 1GH2-70A. (a) Overview photomicrograph of transverse slab of Conotubus and surrounding matrix of laminated rock. Note pyrite or iron oxide rim (gold colour), outer carbonate cement (dark colour), inner carbonate cement (light colour) and central void. Scale bar, $10 \mathrm{~mm}$. (b) Backscattered Z-contrast electron micrograph montage of region defined by white rectangle in $\mathbf{a}$. Fine pyrite or iron oxide rim (Py rim) seen as bright discontinuous specks, surrounding carbonate cements (IC: inner cement; OC: outer cement) and central void (CV). Scale bar, $1 \mathrm{~mm}$. (c) Ultraviolet photoluminescence microscopy of black rectangle region in a, showing zoned carbonate crystals in inner cement. Scale bar, $1 \mathrm{~mm}$. Inset (d) shows higher magnification view of white rectangle in c for better detail of crystal zoning. Scale bar, $500 \mu \mathrm{m}$. (e,f) EDS elemental maps of white rectangle region in $\mathbf{b}$, with calcium (orange) and magnesium (green) overlay shown in e and iron (red) and silicon (blue) overlay shown in $\mathbf{f}$. Scale bar in $\mathbf{f}$ is $1 \mathrm{~mm}$, applicable for $\mathbf{e}$. (g) In situ XRD patterns of host rock light- and dark-coloured laminae, outer carbonate cement within fossil and inner carbonate cement within fossil. Characteristic peak positions of calcite and dolomite are shown in orange and green vertical dashed lines, respectively. The strongest diffraction peaks from calcite and dolomite are labelled with $\mathrm{C}_{104}$ and $D_{104}$, respectively.

tube and the host rock have distinct $\delta^{18} \mathrm{O}$ values. Between fossil-interior cement generations, the outer calcite cements have slightly greater mean $\delta^{13} \mathrm{C}$ and $\delta^{18} \mathrm{O}$ values $\left(\delta^{13} \mathrm{C}=6.1 \pm 0.1 \%\right.$, $\delta^{18} \mathrm{O}=-8.2 \pm 0.2 \%$ ) than the inner dolomite + calcite cements $\left(\delta^{13} \mathrm{C}=5.2 \pm 0.4 \%\right.$ o, $\delta^{18} \mathrm{O}=-9.0 \pm 0.2 \%$ ).

Compaction. Three-dimensional preservation of Conotubus allows an estimate of the compaction ratio of the host sediments. Viewed perpendicular to bedding plane, the calcisiltite/calcilutite microlaminae warp around nearly circular Conotubus tubes (Figs 4a,b,5 and 6). Measurements of microlaminae surrounding Conotubus tubes in comparison with their thickness extending beyond the fossil yields an estimated sediment compaction ratio of $\sim 1.85: 1$. Conotubus tubes show negligible compaction, with a major:minor axis ratio of $\sim 1.15: 1$, although an oblate crosssection may be biological ${ }^{26}$.

\section{Discussion}

Previous analyses of pyritized Palaeozoic Lagerstätten suggest rapid burial into anoxic sediments, which in turn reduces bioturbation, impedes organic deterioration and emplaces the decaying carcasses within the sulfidic BSR zone below the oxic-anoxic boundary in the sediment profile. Further, pyritization-conducive sediments typically have low organic carbon content and abundant reactive iron, serving to focus BSR and pyrite precipitation on decaying carcasses $8,9,13,14,27$. While the Gaojiashan biota is similar to these younger deposits in that pyritized fossils are found in sediments deposited by rapid burial events ${ }^{11}$, there are some key differences. First, the full pyritization-kerogenization preservational gradient from three-dimensional pervasive pyritization to two-dimensional kerogenized compressions, with intermediate or admixed preservational modes, appears to be unique to the Gaojiashan Lagerstätte. Second, the tubular fossils of the Gaojiashan biota 


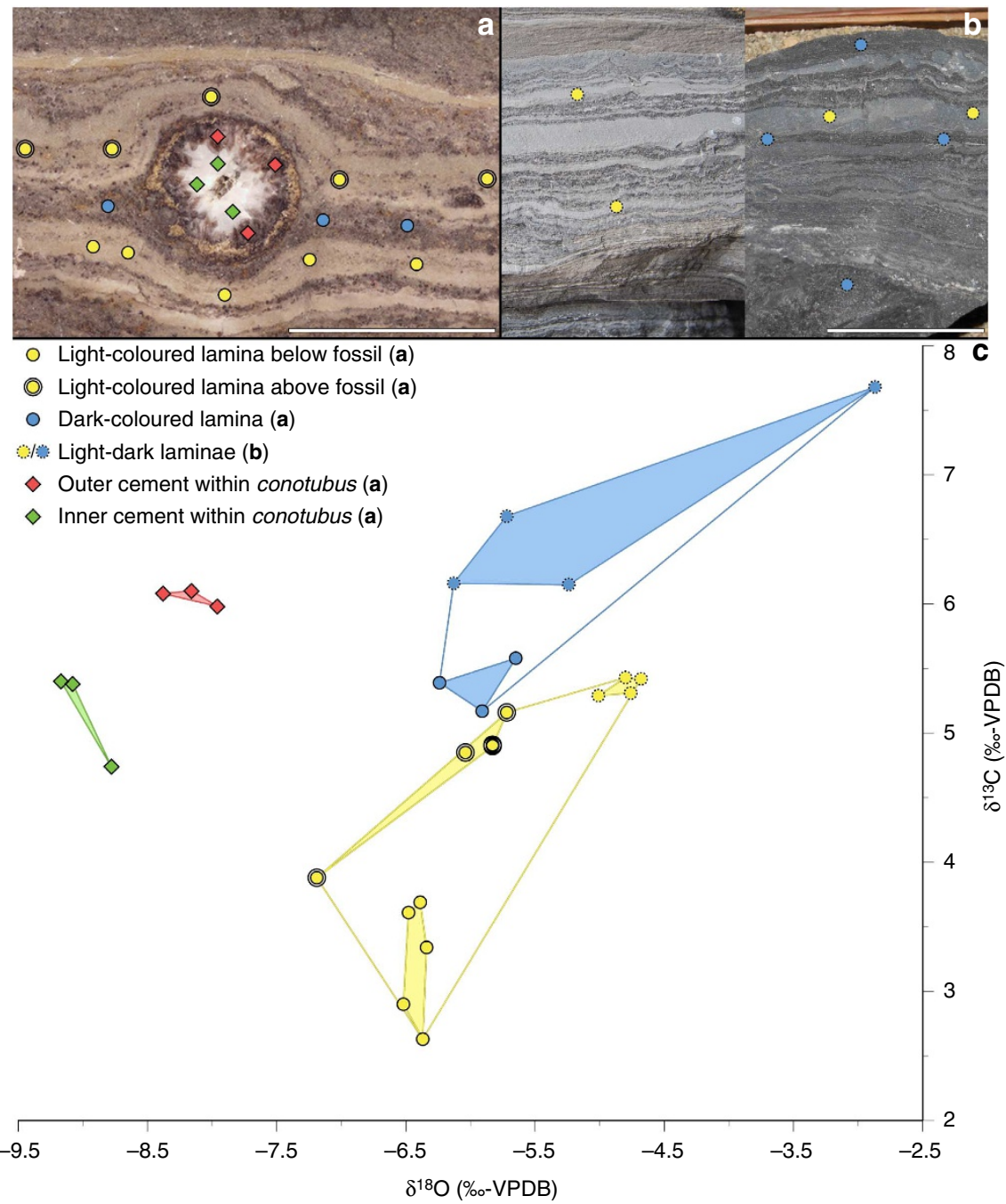

Figure 6 | Host rock and fossil carbonate IRMS $\boldsymbol{\delta}^{\mathbf{1 3}} \mathbf{C}$ and $\boldsymbol{\delta}^{\mathbf{1 8}} \mathbf{O}$ data. (a) Microdrill map of slab 1GH2-70A with Conotubus specimen. Scale bar, $10 \mathrm{~mm}$. (b) Microdrill map of slab (two continuous pieces) without Conotubus fossils. Scale bar, $50 \mathrm{~mm}$. (c) Cross-plot of all $\delta^{13} \mathrm{C}$ and $\delta^{18} \mathrm{O}$ analyses. Convex hulls and nested convex hulls (shaded) show groupings of data by location of microsampling. Yellow points show light-coloured laminae (single circle below fossil and double circle above fossil in $\mathbf{a}$; dashed circle from slab in $\mathbf{b}$ ). Blue points show dark-coloured laminae (single circle contiguous to fossil in $\mathbf{a}$; dashed circle from slab in $\mathbf{b}$ ). Red and green diamonds show outer and inner cements in $\mathbf{a}$, respectively. Keys also applicable for microdrill location maps.

notably do not retain their most labile soft parts ${ }^{10,28}$, showing no evidence of the soft-bodied organisms that lived within these tubes. While some sites of pervasive pyritization show glimpses of highly labile soft-tissue preservation, such as pygnogonid and crustacean musculature from the Hünsruck Slate ${ }^{29,30}$, pervasive pyritization of Conotubus only captures the three-dimensional exterior morphologies of the tubes. The original histology of Conotubus tubes is unknown. However, they have been interpreted as supportive, refractory tissues, either nonbiomineralized or weakly biomineralized ${ }^{28}$.

Building upon the Raiswell et $a .^{31}$ diffusion-precipitation model for pyritization, we can begin to elucidate the progression of pervasive fossil pyritization and provide insights into early diagenetic conditions responsible for the taphonomic styles observed in the Gaojiashan Lagerstätte. According to this model $^{31}$, the locus of mineralization is controlled by the intersection of two diffusion fields. The first arises as a consequence of BSR, driving sulfide outward into the sediment porewaters. The second originates from sediment sources, carrying reactive iron toward the decaying organic nucleus. The intersection of these two diffusion fronts results in supersaturated porewaters with respect to iron sulfide at some distance from the organic nucleus. The spatial trends in both pyrite crystal morphology and $\delta^{34} S_{\mathrm{PY}}$ values of Conotubus fossils are consistent with centripetal pyrite growth controlled by the diffusion-precipitation dynamics of mineralization ${ }^{31}$. Similar to the formation of pyrite rims around chert nodules ${ }^{32}$ and carbonate concretions 8,31 , sulfate reducing bacteria (SRB) metabolized a centrally located organic nucleus, in this case the labile tissues of the Conotubus organism, generating an outward diffusion of sulfide. The sulfide meets with an inward-diffusing reactive iron sourced from ambient porewater, forming a reaction front where pyrite-precursor iron monosulfide ${ }^{33}$ precipitation occurs. As this process proceeds, the organic nucleus is progressively exhausted, resulting in an inward shift in the reaction front (Supplementary Fig. 1).

One complicating issue, however, is that the recalcitrant tube walls of Conotubus would form a barrier to impede but not entirely halt diffusion, resulting in accumulation of sulfide and reactive iron on either side of the tube walls. As such, we must consider another important factor controlling the locus of pyritization: heterogeneous nucleation facilitated by an organic 

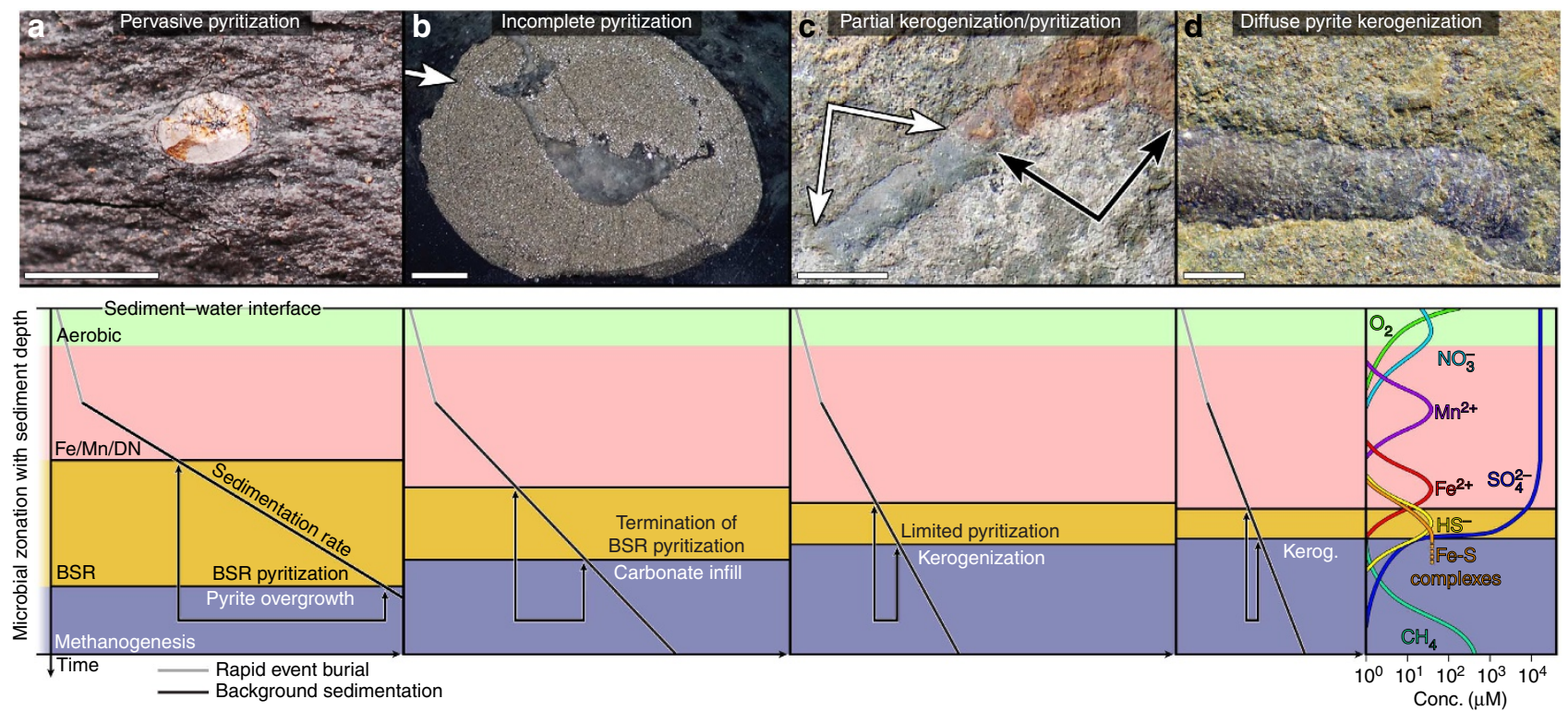

Figure 7 | Pyritization-kerogenization taphonomic gradient. Fossil examples (a-d, upper panels) and proposed taphonomic model (lower panels) with sedimentary microbial zonation. Diagonal lines track the position of the decaying organisms in the sediment column, and the slope of each line represents sedimentation rate. Grey upper diagonal line corresponds to rapid event burial, and black lower diagonal line corresponds to post-burial sedimentation. Brackets indicate the length of time the decaying organism resides in the BSR zone (gold colour), and experiences BSR-mediated pyrite growth, although pyrite overgrowth may continue into underlying methanogenesis zone (blue colour). From left to right, each diagram indicates a shortened residence time in the BSR zone as compared with the previous panel, which could result from either, or both, changes in post-burial sedimentation rate and BSR zone thickness. (a) Pervasively pyritized Conotubus in transverse cross section. Scale bar, $2.5 \mathrm{~mm}$. Diagram shows initial rapid event deposition, followed by slow post-burial sedimentation. (b) Polished transverse cross-section of pyritized Conotubus showing carbonate in the center and thin outer lamina (arrow) representing nested tube wall. Scale bar, $1 \mathrm{~mm}$. Corresponding diagram shows increase in post-burial sedimentation rate and reduction in BSR zone thickness, leading to comparatively earlier termination of pyritization. (c) Specimen of Conotubus with admixed taphonomic mode of pyritization (black arrows) and carbonaceous compression (white arrows). Scale bar, $5 \mathrm{~mm}$. Diagram shows further increase in post-burial sedimentation rate and reduction in BSR zone thickness, yielding partial pyritization and onset of kerogenization once carcass exits BSR zone. (d) Specimen of Conotubus preserved via complete kerogenization with diffuse pyrite. Scale bar, $5 \mathrm{~mm}$. Diagram shows highest post-burial sedimentation rate and thinnest BSR zone, with limited pyritization, and earliest onset of kerogenization. Relative abundances of chemical species at right follows that of refs 47,48 after ref 67 . Fe-S complexes curve shows possible continued pyrite overgrowth from downward diffusion of $\mathrm{HS}^{-} / \mathrm{Fe}^{2+}$. Figures in a-d are reproduced with permission from Elsevier (modified from ref. 1 and ref. 28).

substrate. The individually conserved nested Conotubus tube walls (Figs $1 \mathrm{~b}$ and $7 \mathrm{~b}$ ) may have promoted pyritization by providing a naturally favourable substrate for the initiation of iron sulfide nucleation-an unaccounted-for factor in the traditional model ${ }^{31}$.

The ability of an organic substrate, such as the tube walls, to promote mineralization can be readily justified within the constructs of classical nucleation theory. For a cube-shaped nucleus, the relationship between the free energy barrier opposing the formation of a stable nucleus in solution (homogeneous case) and on a foreign substrate is: $\Delta G_{\text {het }}^{*}=\Delta G_{\text {hom }}^{*}\left(\frac{\alpha_{\text {het }}}{2 \alpha_{\mathrm{hom}}}\right)$, where $\alpha_{\mathrm{hom}}$ and $\alpha_{\text {het }}$ are the interfacial energies of the homogeneous and heterogeneous nuclei. Although $\alpha_{\text {het }}$ depends on the balance between the liquid-nucleus, liquid-substrate and substratenucleus interfacial tensions, a simple analysis shows that if $\alpha_{\text {hom }} \approx \alpha_{\text {het }}$, the free energy barrier opposing nucleation at a surface is reduced to half of the homogeneous barrier. As nucleation rate shows an exponential dependence on $\Delta G^{*}$, this translates into a substantial increase in the rate of surface nucleation. Indeed, nucleation rates depend strongly on the chemical nature and physical structure of the organic interface. For instance, $\mathrm{NH}_{3}^{+}$terminated surfaces can be completely passive to the formation of amorphous $\mathrm{SiO}_{2}$; however, under identical conditions, $\mathrm{NH}_{3}^{+} / \mathrm{COO}^{-}$surfaces promote $\mathrm{SiO}_{2}$ deposition to the extent that the organic may be coated by a nearly-coherent nanoscale layer of amorphous material within a few hours ${ }^{34}$. Moreover, as evidenced by calcite nucleation on polysaccharide matrices ${ }^{35}$, significant variations in the surface nucleation rate may occur between biopolymers with similar functionalities, with the specific order of substrate preference depending chiefly on supersaturation.

During the earliest stages of microbially induced degradation, when nucleation sites on the tube surface are most abundant, pyritization is dominated by precipitation of abundant micrometric crystals as are observed at the outer edges of the Conotubus specimens. The size and location of the crystallites indicates that the organic tube-wall surface likely plays a role in directing the onset of nucleation, and that the pyrite supersaturation state, $\sigma$, was relatively high as compared with the later stages of mineralization when pyritization proceeds through coarsening of existing crystals rather than formation of new crystals. This interpretation is supported by the nucleation rate equation, $J_{n}=A e^{-\Delta G^{*} / k_{B} T}=A e^{-B / \sigma^{2}}$, where $A$ is a preexponential constant (whose units represent the number of molecules attaching to a critically-sized nucleus per unit time and surface area), $B$ is a constant that describes the shape of the nucleus, $T$ is temperature, $k_{\mathrm{B}}$ is the Boltzmann constant, $\Delta G^{*}$ is free energy matching the thermodynamic barrier opposing nucleation and $\sigma$ is supersaturation $\left(\ln \frac{\text { ion activity product }}{\text { solubility product }}\right)$. This equation shows that an increase in supersaturation state generally results in a higher number of nuclei per unit area of substrate or volume of solution in the case of homogeneous nucleation. As compared with any soft body tissues of the Conotubus organism, the tube walls must have provided the most chemically favourable 
nucleation sites for initiation of pyrite growth. Pyrite crystals in these regions are isotopically heavier $\left(\delta^{34} S_{P Y}\right.$ typically $>-25 \%$; Fig. 2a,d,e) than those in the tube interior, indicating a progressive decline in BSR rate throughout the pyritization process and corresponding relaxation in diffusion-limited sulfate availability. The inferred sulfate limitation in initial pyritization may seem contradictory to the high $\Delta^{34} S_{\text {CAS-PY }}$ values (Supplementary Note 1). However, oxidative recycling of sulfide and oxidation of detrital pyrite entrained in microturbidites ${ }^{14}$ likely supplied ${ }^{34} \mathrm{~S}$-depleted sulfate for pyritization, thereby contributing to the high $\Delta^{34} S_{\text {CAS-PY values. As BSR continues }}$ over time, labile tissues are diminished and BSR necessarily slows because of decreasing availability of metabolizable organic carbon rather than sulfate exhaustion or deep burial, which would instead yield a shift towards higher $\delta^{34} S_{P Y}$ values. As a result of slowed BSR, sulfide production rate would drop, supersaturation levels with respect to iron sulfide would decrease and nucleation would be disfavoured. Thus, iron sulfide precipitation is focused on overgrowing existing crystals, leading to the formation of millimetric crystals. During this shift, $\delta^{34} S_{P Y}$ values would decrease as the BSR system switches from sulfate limitation to organic limitation. The expected result is a U-shaped $\delta^{34} \mathrm{~S}_{\mathrm{PY}}$ profile as observed in some specimens (Fig. 2d,e), although this profile can be obscured by pyrite overgrowth (see Discussion below).

From the understanding of how the pyritization process proceeds and expectations for resultant sulfur isotopic trends (Supplementary Note 1), we can then shift our focus to resolving the geochemical constraints for pervasive pyritization. With the first dissociation constant of $\mathrm{H}_{2} \mathrm{~S}$ at $1.05 \times 10^{-7}\left(\mathrm{~K}_{1}=\left[\mathrm{H}^{+}\right]\right.$ $\left[\mathrm{HS}^{-}\right] /\left[\mathrm{H}_{2} \mathrm{~S}\right]$ ) and seawater $\mathrm{pH}$ typically constrained to $\sim 7.5-8.5$, $\mathrm{HS}^{-}$is the dominant dissolved sulfide species. Thus, we can write the precipitation of pyrite as $\mathrm{Fe}^{2+}+\mathrm{S}^{0}+\mathrm{HS}^{-} \rightarrow \mathrm{FeS}_{2}+\mathrm{H}^{+}$, such that the equilibrium solubility product for pyrite is given as $K_{\mathrm{sp}}=\left[\mathrm{Fe}^{2+}\right]\left[\mathrm{HS}^{-}\right] / 10^{-\mathrm{pH}}=10^{-16.35}$ (ref. 36). With activity coefficients for $\mathrm{HS}^{-}$and $\mathrm{Fe}^{2+}$ in seawater at 0.67 and 0.26 (ref. 37), we can then calculate the apparent solubility product for pyrite as $K_{\mathrm{sp}}^{\prime}=\frac{K_{\mathrm{sp}}\left(10^{-\mathrm{pH}}\right)}{\gamma_{\mathrm{F}^{2}+\gamma^{\mathrm{HS}}-}}=8.1 \times 10^{-24}\left(\mathrm{M}^{2}\right)$ at the low end of normal seawater $\mathrm{pH}$. As such, given the Raiswell et al. ${ }^{31}$ model assumption of the estimated ratio of reservoir concentrations $\left(C^{0}\right)$ of sulfur to iron, $C_{S}^{0}: C_{F e}^{0}<0.1$ (that is, $\left[\mathrm{Fe}^{2+}\right] \geq 10 \times\left[\mathrm{HS}^{-}\right]$), for localized pyrite formation at the site of decay ${ }^{31}$, reactive iron must be greater than approximately $9 \times 10^{-12} \mathrm{M}$ to drive pyrite precipitation, well below modern observations of anoxic sediments at $<10^{-4} \mathrm{M}$ (refs 8,31). Because the majority of the fossils in the Gaojiashan Lagerstätte exhibit three-dimensional pervasive pyritization ${ }^{1}$, we can surmise an excess of available sediment/porewater reactive iron. Assuming a decay constant of $0.1-1.0$ per year (reported for organic decay in marine sediments ${ }^{38}$ ) and an organic nucleus radius of $0.1-1.0 \mathrm{~cm}$ (appropriate for Conotubus with a maximum diameter of $1.2 \mathrm{~cm}$ (ref. 28)), porewater dissolved sulfide concentrations of $<10^{-4} \mathrm{M}$ are required for soft tissue pyritization (Fig. 3 in ref. 31). As localized pyritization of highly labile tissues occurs when $C_{S}^{0}$ : $C_{F e}^{0}<0.1$ (ref. 31 ), $\mathrm{Fe}^{2+}$ content in porewater may have been up to $10^{-3} \mathrm{M}$. We can thus reasonably constrain porewater $\mathrm{Fe}^{2+}$ content in Gaojiashan sediments between $9 \times 10^{-12} \mathrm{M}$ and $10^{-3} \mathrm{M}$, justified by the lack of labile soft-tissue pyritization in this Lagerstätte.

In incompletely pyritized but three-dimensional Conotubus tubes, alkalinity generated during BSR (Supplementary Table 3) and bacterial $\mathrm{Fe}(\mathrm{III})$ reduction (BFeR: $\mathrm{CH}_{3} \mathrm{COO}^{-}+$ $\left.8 \mathrm{Fe}(\mathrm{OH})_{3} \rightarrow 2 \mathrm{HCO}_{3}^{-}+8 \mathrm{Fe}^{2+}+15 \mathrm{OH}^{-}+5 \quad \mathrm{H}_{2} \mathrm{O}\right)$ could contribute to carbonate infill assuming appropriately basic microenvironmental $\mathrm{pH}$ levels to facilitate calcite precipitation $^{32,39}$. While similar relatively heavy $\delta^{13} \mathrm{C}$ values of host rock and fossil cement render BSR- or BFeR-sourced bicarbonate as insignificant contributors, dissolved sulfide is observed to enhance crystallization of calcite and dolomite ${ }^{40}$, possibly contributing to early calcite cementation. In addition, SRB exopolysaccharides commonly incorporate metal cations (such as $\mathrm{Mg}$ and $\mathrm{Fe}$ ), which could facilitate precipitation of high$\mathrm{Mg}$ calcite and ankerite ${ }^{41}$. The $\sim 2 \%$ difference between carbonate cement $\delta^{18} \mathrm{O}$ values within the Conotubus specimen and host carbonates, but broadly similar $\delta^{13} \mathrm{C}$ values (Fig. $6 \mathrm{c}$ ), suggest that the cements may have been slightly influenced by diagenetic fluids without significant alteration of carbon isotopic composition. Slightly lower $\delta^{18} \mathrm{O}$ and $\delta^{13} \mathrm{C}$ values in the inner versus outer cements indicates a stronger influence of diagenetic fluids on the inner cementation, consistent with petrographic evidence showing a later origin than the outer cements. The relatively small isotopic difference between the cements and sedimentary matrix suggests that carbonate cementation may have occurred shortly after the cessation of pyritization, playing a constructive preservational role by enhancing the rigidity of partially pyritized tubes before sediment compaction.

While we have established that both pervasive and incomplete pyritization must have predated sediment compaction based on warping host rock microlaminae encasing the Conotubus fossils, we can further constrain the duration of the pyritization process. To do so, we must consider requisite levels of sulfate, reactive iron and metabolizable organic material. On the basis of the size of Conotubus specimens, with a maximum diameter of $12 \mathrm{~mm}$ and length of $3-80 \mathrm{~mm}$ (ref. 28), the amount of sulfate required for complete pyritization will follow $M_{\text {sulfate }}=2 \frac{V * \rho}{M_{\text {pyrite }}^{\prime}}$, where $V$ is the volume of the Conotubus tube, $\rho$ is the density of pyrite $(\approx 5 \mathrm{~g}$ per $\left.\mathrm{cm}^{3}\right)$ and $M_{\text {pyrite }}$ is the molar mass of pyrite $\left(\approx 120 \mathrm{~g} \mathrm{~mol}^{-1}\right)$. Using $V=\pi^{*} r^{2 *} l$ for the volume of a cylinder, with Conotubus radius $(r)$ and length $(l)$ simplified as 5 and $40 \mathrm{~mm}$, the total sulfate required is 0.26 moles. The amount of reactive iron needed is 0.13 moles. The amount of organic carbon needed varies by the electron donor compound used (largely fermentative end products; Supplementary Table 3). For simplicity, we use BSR of acetate, which, in accordance with the above constraints, requires 0.52 moles of organic $C$. If we then assume that the interior volume of Conotubus tube is completely full of soft tissue (an overestimate), with a nested tube-wall thickness of $1 \mathrm{~mm}$ (Fig. 1b), the volume of soft tissue that contains metabolizable organic material using the same dimensions as above is $\sim 2 \mathrm{~cm}^{3}$. Assuming that the soft tissue was pure amorphous carbon (density $=\sim 1.8 \mathrm{~g} \mathrm{~cm}^{-3}$ ), 0.52 moles would occupy a volume of $\sim 3.5 \mathrm{~cm}^{3}$, a substantially larger volume than is available within the Conotubus tube. As such, given realistic carbon contents in animal tissues, we can deduce that there is a deficit of endogenous carbon to account for the volume of pyrite precipitated-which is clearly problematic, but disregarded for now and revisited in our model description below. On the basis of these calculations and high-end rates of sulfate reduction in Ediacaran sediments $\left(6.935 \mathrm{mmol} \mathrm{cm}{ }^{-3}\right.$ per year according to ref. 42 , with pervasive anoxic conditions and higher metabolizability of organics before the evolution of vascular plants $\left.{ }^{32,42-44}\right)$, we can calculate an approximate timeframe for generating sufficient $\mathrm{HS}^{-}$to pervasively pyritize a Conotubus tube with a $3.14 \mathrm{~cm}^{3}$ total volume. If the 0.26 moles of $\mathrm{SO}_{4}^{2-}$ is derived entirely endogenously within a Conotubus tube, a total of $82.8 \mathrm{mmol}$ $\mathrm{HS}^{-}$per $\mathrm{cm}^{3}$ is required for pyritizing the full volume of the tube. At a rate of $6.935 \mathrm{mmol} \mathrm{cm}^{-3}$ per year, a total of $\sim 12$ years would be required to generate enough $\mathrm{HS}^{-}$for pyritization. Even at modern rates of sulfate reduction, such as measured rates of $0.1 \mathrm{mmol} \mathrm{cm}{ }^{-3}$ per year (ref. 45 ), this yields 828 years to generate 
enough $\mathrm{HS}^{-}$for pyritization of moderately sized Conotubus tubes. The decaying organism is a BSR hotspot, which should pull in both $\mathrm{SO}_{4}^{2-}$ and $\mathrm{Fe}^{2+}$ from the surrounding microenvironment (as opposed to assumed steady-state equilibrium ${ }^{31}$ ), thus these cited bulk-sediment rates may overestimate the pyritization time. It is important to note, however, that these estimates assume that $\mathrm{HS}^{-}$is: (1) a rate-limiting factor for pyrite precipitation and (2) entirely derived from BSR in and around the decaying Conotubus organism in the BSR zone. As discussed below, these assumptions may not be valid.

From these and previously reported observations ${ }^{1}$, the data presented herein allow for a pragmatic approach to consider the timing, processes, and interrelationship of pyritization and kerogenization. First, the pyritization process is likely initiated in the BSR zone in the sediment column. The sediment column typically consists of an aerobic respiration zone just beneath the water-sediment interface, followed by an anaerobic zone with nitrate, manganese and iron reduction, then the BSR zone, and finally the methanogenesis zone at depth ${ }^{46}$ (Fig. 7). For fossil pyritization to occur in the BSR zone, factors directly responsible for BSR-mediated pyrite mineralization-the availability of sulfate, reactive iron, metabolizable organic material and positioning of the carcass within the BSR zone-must overlap with commonly invoked facilitating conditions such as rapid sedimentation and burial, low bioturbation and sediment anoxia. These factors are intimately related. For example, sedimentation rate influences the availability of reactive iron, sulfate and organic carbon in the sediments, thus controlling the thickness of the BSR zone and ultimately how much time the decaying carcass spends here. Because sedimentation rate plays such an important role, we propose a unifying model in which sedimentation rate was the primary factor controlling the pyritization-kerogenization gradient as observed in the Gaojiashan biota (Fig. 7).

To help explain the model, we focus on four representative preservational styles along the pyritization-kerogenization gradient: (1) pervasive pyritization, (2) incomplete threedimensional pyritization, (3) partial kerogenization with abundant pyrite association and (4) kerogenization with limited or highly diffuse pyrite association. For complete pyritization (Fig. 7a), initial pyrite mineralization must occur rapidly to circumvent compression, and must continue to fill the entire volume of the organism. If full pyritization occurs entirely in the BSR zone, then the decaying carcass must stay in the BSR zone for a sufficient amount of time, requiring a thick BSR zone and/or a slow sedimentation rate following burial. The initial smothering event that entrapped the Conotubus organism rapidly placed it below the oxic zone of aggressive aerobic decay, and subsequent sedimentation proceeded sufficiently slowly to ensure a long enough duration in the BSR zone for complete pyritization. This scenario is consistent with the $\delta^{34} S_{\mathrm{PY}}$ data, with greater outeredge values suggesting an initial period of relatively rapid BSR, ensuring three-dimensional structural integrity, followed by a progressive decrease in BSR rate (Supplementary Fig. 1) accompanying greater isotopic fractionation and lower $\delta^{34} S_{\mathrm{PY}}$ values. Volumetric considerations, however, suggest a shortage of organic fuel from the Conotubus soft-tissue itself, which would require either an exogenous source of carbon or production of de novo organic carbon within the organic nucleus (for instance, by in situ chemoautotrophs) to continue fuelling further sulfide production once the labile soft tissues of Conotubus were exhausted. Alternatively, pyritization could continue in the methanogenesis zone where BSR is disfavoured but residual or downward-diffusing porewater $\mathrm{HS}^{-}$(or $\mathrm{Fe}-\mathrm{S}$ complexes ${ }^{47}$ ) support pyrite overgrowth and continued pyritization. This extended period of overgrowth may not show any clear textural change, but would obscure the anticipated U-shaped $\delta^{34} S_{P Y}$ profile because residual porewater $\mathrm{HS}^{-}$tends to have greater $\delta^{34} S$ values. In combination, the observed subtle textural variations (Fig. 2b,c) and higher $\delta^{34} S_{\mathrm{PY}}$ values along millimetric crystal edges may support this alternative scenario. Regardless, the keys for complete pyritization are rapid burial and initial pyritization to maintain structural integrity, followed by prolonged pyrite overgrowth within and perhaps below a relatively thick BSR zone to completely fill Conotubus tubes with pyrite.

Incomplete but three-dimensional pyritization (Fig. 7b) requires the same facilitating taphonomic conditions as complete pyritization, including rapid placement in the BSR zone and initiation of pyritization to maintain three-dimensionality, but instead experiences closure of the pyritization process before complete infilling of the Conotubus tube with pyrite. As such, temporal limitation of one or more of the required chemical components, such as diffusive extinction of sulfate, may limit the extent of the BSR zone. With or without BSR zone restriction, the decaying Conotubus organism is likely pushed down into the methanogenesis zone due to high post-burial sedimentation rate, such that pyritization in the BSR zone is prematurely terminated. Alternatively, these incompletely pyritized tubes may persist within the BSR zone, but with cessation of pyritization due to exhaustion of metabolizable organic material and a shortage of exogenous carbon input. The interior space originally occupied by the Conotubus animal then becomes a central void, which is subsequently infilled with carbonate cements. The timing of carbonate cementation may depend on the electron donor used in BSR (Supplementary Table 3). Two scenarios are plausible: (1) the BSR respiration pathway does not produce acidity and carbonate cementation is synchronous with pyritization; or (2) carbonate cementation follows dissipation of a lower $\mathrm{pH}$ microenvironment generated with BSR production of acidity. In either case, no organic material remains or at least none is preserved through kerogenization. Regardless of which alternative is more realistic, the true preservational distinction between complete and incomplete three-dimensional pyritization hinges on the duration, not the initiation, of pyrite formation. With regard to complete pyritization, we suggest that continuing pyrite overgrowth is necessary for complete Conotubus tube infill, whereas incompletely pyritized tubes instead are infilled with carbonate cements after premature termination of pyritization.

At the other end of the Gaojiashan preservational spectrum are kerogenized carbonaceous compressions. While models for kerogenization invoke the same facilitating taphonomic conditions for pyritization, three-dimensional structural rigidity is not preserved, and instead organic tissues are stabilized to form geologically robust but two-dimensionally compressed carbonaceous remains. In the kerogenization taphonomic modes, pyritization is necessarily limited for tissues to be preserved as carbonaceous compressions. The potential key is a rapid postburial sedimentation rate and/or a narrower BSR zone, such that the fossilizing Conotubus tube is much more quickly moved through the BSR zone with little pyritization, thus positioning the decaying organism within the methanogenesis zone shortly following the onset of decay. In such a case, Conotubus tubes that exhibit an appreciable amount of pyritization (Fig. 7c) may have stayed in the BSR zone long enough to facilitate localized pyritization but not extensively sustained for pyritization to maintain three-dimensional structural integrity. Kerogenized Conotubus with only diffuse pyrite (Fig. 7d) likely experience the majority of preservation within the methanogenesis zone during the earliest stages of decay, thus spending only very limited time in the BSR zone due to a high post-burial sedimentation rate and/or a narrowed BSR zone. Following these conditions, the fossil is predominantly comprised of carbonaceous remains from kerogenization within the 
methanogenesis zone. Methanogens are incapable of decomposing higher molecular weight organic compounds, commonly using acetate as the terminal electron acceptor ${ }^{48}$ (generalized: $\mathrm{CH}_{3} \mathrm{COO}^{-}+\mathrm{H}_{2} \mathrm{O} \rightarrow \mathrm{CH}_{4}+\mathrm{HCO}_{3}^{-}$). If the breakdown of highmolecular weight compounds via bacterial fermentation (generalized: $\mathrm{C}_{6} \mathrm{H}_{12} \mathrm{O}_{6}+4 \quad \mathrm{H}_{2} \mathrm{O} \rightarrow 2 \quad \mathrm{CH}_{3} \mathrm{COO}^{-}+2 \quad \mathrm{HCO}_{3}^{-}+4$ $\mathrm{H}^{+}+4 \mathrm{H}_{2}$ ) is mostly limited to metabolically labile tissues, and aggressive aerobic degradation (generalized: $\mathrm{CH}_{3} \mathrm{COO}^{-}+\mathrm{O}_{2} \rightarrow 2$ $\left.\mathrm{CO}_{2}+\mathrm{H}_{2} \mathrm{O}+\mathrm{OH}^{-}\right)^{48}$ was limited as a result of rapid burial, only the most recalcitrant structures such as the Conotubus tube walls will enter the fossil record. A few alternative scenarios should also be considered. First, the Conotubus remains may indeed undergo degradation within the BSR zone, but instead occupy microenvironments that are substantially limited in either or both reactive iron or sulfate thus hindering pyrite precipitation. Second, the invocation of minimal ambient organic material ${ }^{13}$ for pyritization may not hold in cases of kerogenization. That is, SRB may prefer disseminated organic sources if Conotubus is emplaced within comparatively more organic-rich sediments, with Conotubus thus avoiding BSR-degradation and localized pyritization. Regardless, in either case, organic degradation is clearly limited to labile tissues, such that only the recalcitrant tissues are eventually preserved as kerogens.

Previous biostratinomical analysis of the late Ediacaran Gaojiashan Lagerstätte has established that event deposits played an important role in the preservation of Gaojiashan fossils ${ }^{11}$, but the post-burial mineralization processes leading to the observed pyritization-kerogenization gradient of preservation remain elusive. On the basis of geochemical analyses of threedimensionally pyritized Conotubus specimens, we have established that the pyritization process proceeded centripetally from a rim of micrometric pyrite nucleated on the tube wall and fuelled by SRB degradation of labile tissues within the tube. This process can be described using a diffusion-precipitation model $^{31,32}$, modified to account for the role of an organic tube in promoting the onset of pyritization by providing a preferable substrate for nucleation. We suggest that preservation along the pyritization-kerogenization gradient can be understood as variations in the placement and duration of the carcass within the BSR and methanogenesis zones. The amount of time spent in each zone is principally influenced by post-burial sedimentation rate and/or BSR zone thickness, the latter of which is also related to the availability of metabolizable organic material and sulfate. The fossils that show three-dimensional pyritization, whether pervasive or incomplete, spend more time in the BSR zone. In contrast, those that are two-dimensional carbonaceous compressions, either with extensive or diffuse pyrite association, are more rapidly buried in the methanogenesis zone. In each case, degradation is required for preservation, and each mode may be viewed as a complex balance between decay and mineralization. These preservation processes, whether pyritization or kerogenization, are governed by the same suite of facilitating taphonomic conditions, are primarily influenced by microbial decay pathways, and differ principally in the duration of interactions with the BSR and methanogenesis zones. Thus, the scientific conversation regarding contributing factors of Beecher's Trilobite-type pyritization and Burgess Shale-type carbonaceous compression should be shifted from facilitating factors such as a lack of bioturbation ${ }^{49,50}$ and bed-capping carbonate cements ${ }^{18}$, to those that drive mineralization and stabilization processes and are directly responsible for fossil preservation.

\section{Methods}

Materials. The Conotubus hemiannulatus specimens examined in this study were collected from the Gaojiashan Member of the Dengying Formation at Gaojiashan in Ningqiang county, southern Shaanxi Province, South China ${ }^{28}$. Located in the northwest margin of the Yangtze Platform (Supplementary Fig. 2A), the Gaojiashan region has numerous exposures of Ediacaran-Cambrian strata with broadly similar stratigraphy (from lower to upper): siliciclastic-dominated Doushantuo Formation; dolostone-dominated Dengying Formation; and phosphorite and carbonate of the basal Cambrian Kuanchuanpu Formation. The Dengying Formation is tripartite (Supplementary Fig. 2B), consisting of (from lower to upper): thick-bedded, vuggy, peritidal dolostones of the 300-m-thick Algal Dolomite Member; thin-bedded calcareous siltstones, mudstones and limestones of the $\sim 55$-m-thick Gaojiashan Member that hosts the Gaojiashan Lagerstätte; and thick-bedded, vuggy, microbially laminated-tostromatolitic, peritidal dolostone of the $\sim 200$-m-thick Beiwan Member. Correlation with the radiometrically dated Dengying Formation in the Yangtze Gorges suggests that the Gaojiashan Lagerstätte is constrained between 551 and $541 \mathrm{Myr}$ ago ${ }^{51,52}$.

Gaojiashan fossils mostly occur within millimetric beds of fine-grained calcisiltite-siltstone of the Gaojiashan Member, interpreted to have been deposited below storm wave base. Biostratinomic analysis of the Gaojiashan biota indicates that rapid event deposition played a key role in the exceptional preservation of Gaojiashan fossils ${ }^{11}$. The Gaojiashan biota is dominated by weakly biomineralized to non-biomineralized tubular and ribbon-like fossils (for example, Cloudina Conotubus, Gaojiashania, Shaanxilithes and Sinotubulites), and also includes protolagenid microfossils, algal debris, ichnofossils and microbial mat textures ${ }^{11,28,53-59}$. The focus of this study, Conotubus hemiannulatus, is currently only known from the Gaojiashan Lagerstätte. Showing similarities in construction (Fig. 1d) and epibenthic life-mode, Conotubus has been interpreted as a possible evolutionary precursor of Cloudina ${ }^{28,55}$. Conotubus differs from Cloudina in its tube composition, as Conotubus was likely only weakly biomineralized at most ${ }^{28}$. The fossiliferous unit occurs $\sim 18-49 \mathrm{~m}$ above the base of the Gaojiashan Member, with the Conotubus-dominated biofacies within the $26-39 \mathrm{~m}$ range corresponding to positive $\delta^{13} \mathrm{C}$ and negative $\delta^{18} \mathrm{O}$ excursions ${ }^{60}$. Rare earth elemental

geochemistry ${ }^{60}$ suggests that the Gaojiashan Member was deposited in a restricted shallow sea environment, with riverine influx, common storm deposition influence ${ }^{11}$, and high bioproductivity.

The samples studied herein were collected from calcareous siltstones $28-45 \mathrm{~m}$ above the base of the Gaojiashan Member (Supplementary Fig. 2B). Three pyritized Conotubus hemiannulatus specimens, collected $28-29 \mathrm{~m}$ above the base of the Gaojiashan Member ( $\star 1$ in Supplementary Fig. $2 B$ ), were trimmed to sub-25-mm pieces, vacuum embedded in low-viscosity epoxy, and then ground and polished to make two longitudinal cross-sections and one transverse cross-section. These three specimens (reposited at the University of Missouri, Columbia; specimen numbers: GJS-Cono001 to GJS-Cono003) were imaged and compositionally analysed using scanning electron microscopy (SEM)/energy-dispersive X-ray spectroscopy (EDS) Sulfur isotopic compositions of pyrite $\left(\delta^{34} S_{P Y}\right.$, reported as \%o-VCDT) were measured in situ using SIMS and on microdrilled powders using IRMS. A fourth specimen, collected at 37-38 $\mathrm{m}$ above the base of the Gaojiashan Member ( $\star 3$ in Supplementary Fig. 2B), on a larger slab was polished to make a transverse cross-section. This specimen (reposited at the Virginia Tech; specimen number: $1 \mathrm{GH} 2-70 \mathrm{~A}$ ) was analysed using SEM/EDS, ultraviolet photoluminescence microscopy and in situ X-ray diffraction (XRD). Both specimen number 1GH-70A and a non-fossiliferous slab, collected at 44-45 $\mathrm{m}$ above the base of the Gaojiashan Member ( $\star 4$ in Supplementary Fig. 2B), were microdrilled for IRMS $\delta^{13} \mathrm{C}$ and $\delta^{18} \mathrm{O}$ analyses (see Fig. 6a,b for drilling maps). An additional slab, collected $32 \mathrm{~m}$ above the base of the Gaojiashan Member ( $\star 2$ in Supplementary Fig. 2B), was analysed via IRMS for $\delta^{34} S_{\text {CAS }}$ (data reported in Supplementary Table 1).

Scanning electron microscopy. All SEM and EDS analyses (Fig. 2a-c,g; and Fig, 3a,c; Fig. 4a,b,e-g; Fig. 5b,e,f) were conducted using an FEI company Quanta 600 field-emission variable-pressure SEM with an integrated Bruker AXS Quantax 400 high-speed silicon-drift EDS detector (Virginia Tech Institute for Critical Technology and Applied Science Nanoscale Characterization and Fabrication Laboratory). The specimens were analysed in high-vacuum mode $\left(\sim 6 \times 10^{-6}\right.$ Torr), $\sim 10 \mathrm{~mm}$ working distance, $20 \mathrm{keV}$ beam accelerating voltage, 5.0 spot size (approximation of beam diameter and specimen current) and a system take-off angle of $35^{\circ}$ for EDS analyses. EDS point scans were conducted for $100 \mathrm{~s}$ live-time, and elemental maps were collected for $600 \mathrm{~s}$ live-time.

Secondary ion mass spectroscopy. All SIMS analyses followed $\delta^{34} S_{\text {PY }}$ methods described in ref. 32, using a Cameca 7f GEO magnetic sector system (Virginia Tech Institute for Critical Technology and Applied Science Nanoscale Characterization and Fabrication Laboratory). A Cs ${ }^{+}$primary beam with $1 \mathrm{nA}$ current at an energy of $20 \mathrm{kV}$ was used to sputter the specimen, and the ${ }^{32} \mathrm{~S}$ and ${ }^{34} \mathrm{~S}$ isotopes were detected using dual Faraday cup detectors from a $\sim 10 \mu \mathrm{m}$ analytical spot. Mass resolution of $\sim 2,000 \mathrm{~m}$ per $\Delta \mathrm{m}$ was used to resolve the ${ }^{32} \mathrm{~S}$ from ${ }^{16} \mathrm{O}_{2}$ mass interference. A total of 214 spots across three specimens were analysed (Supplementary Table 1; Figs 2a,d-f; Fig. 3a,b; Fig. 4b-d), and measured $\delta^{34} S_{P Y}$ values are reported as \%o deviation from VCDT (Vienna Cañon Diablo Troilite; ${ }^{34} \mathrm{~S} /{ }^{32} \mathrm{~S}=0.0450045$ ref. 61$)$ calibrated via a Balmat pyrite standard $\left(\delta^{34} \mathrm{~S}_{\text {Balmat }}=15.1 \%{ }^{\circ}\right.$-VCDT; ${ }^{44} \mathrm{~S} /{ }^{32} \mathrm{~S}=0.04568407$ refs 62,63$)$. Each SIMS spot measurement consisted of 10 cycles of ${ }^{34} \mathrm{~S} /{ }^{32} \mathrm{~S}$ ratios acquired from the same physical spot after $\sim 2$-min presputter to remove potential surface contamination. 
The duration of individual spot analyses was $\sim 5 \mathrm{~min}$, not including presputter. One-sigma errors of sample $\delta^{34} S_{\mathrm{PY}}$ measurements were calculated from the instrumental standard error report of the 10 cycles, converted to \%o-VCDT.

\section{Ultraviolet photoluminescence and X-ray diffraction. Photoluminescence} microscopy and in situ XRD analyses were conducted on a UV microscope (Olympus BX51) and a Rigaku Rapid II X-ray diffraction system with a 2D image plate, in the S.W. Bailey X-ray Diffraction Laboratory, Department of Geoscience, University of Wisconsin. The polished cross-sectional slab of Conotubus, specimen number $1 \mathrm{GH} 2-70 \mathrm{~A}$, was used in the analyses. All diffraction patterns were collected using reflection mode. Single-crystal diffraction patterns were also obtained to understand the crystallographic relationship between the dolomite and calcite in the zoned crystals (Fig. 5c,d,g).

Isotope ratio mass spectroscopy. Carbon and oxygen IRMS analyses were carried out at the University of Maryland and the Northwest University in Xi'an. Approximately $100 \mu \mathrm{g}$ microdrilled powder was allowed to react for $10 \mathrm{~min}$ at $90^{\circ} \mathrm{C}$ with anhydrous $\mathrm{H}_{3} \mathrm{PO}_{4}$ in a Multiprep inlet system connected to an Elementar Isoprime dual inlet mass spectrometer for $\delta^{13} \mathrm{C}$ and $\delta^{18} \mathrm{O}$ analysis. Isotopic results are expressed in the standard $\delta$ notation as \%o deviation from VPDB. Uncertainties determined by multiple measurements of NBS-19 were better than $0.05 \%$ o $(1 \sigma)$ for both $\mathrm{C}$ and $\mathrm{O}$ isotopes.

Carbonate-associated sulfate sulfur IRMS analysis was carried out at Indiana University. After trimming to remove visible veins and weathering rinds and ultrasonically cleaning in distilled deionized water, $56.3 \mathrm{~g}$ of whole rock was crushed and pulverized into powder of $<200$ mesh size $(74 \mu \mathrm{m})$ using a splitdiscus mill. Sulfate extraction followed the recommended protocol of ref. 64. Ultrapure Milli-Q water (18 M 2 ), purified $\mathrm{NaCl}$, and distilled $\mathrm{HCl}$ were used to create solutions for leaching and acid digestion of the sample. The powder was immersed in $10 \% \mathrm{NaCl}$ solution under constant magnetic stirring at room temperature until no sulfate was present in filtrate solutions. After water-leaching steps, the carbonate sample was dissolved in $10 \% \mathrm{HCl}$ solution. The slurry was decanted and vacuum filtered through a $0.45-\mu \mathrm{m}$ cellulose membrane filter. The acid-leached sulfate was collected as $\mathrm{BaSO}_{4}$ by adding saturated $\mathrm{BaCl}_{2}$ solution. All collected $\mathrm{BaSO}_{4}$ samples were further purified by the DDARP method of ref. $65 . \mathrm{BaSO}_{4}$ was converted to $\mathrm{SO}_{2}$ using an Elemental Analyzer at $990{ }^{\circ} \mathrm{C}$ and the $\delta^{34} \mathrm{~S}_{\mathrm{CAS}}$ measurement was conducted on a Thermo-Electron Delta V Advantage mass spectrometer in continuous-flow mode.

In addition, pyrite from samples GJS-Cono001 to GJS-Cono003 was microdrilled and analysed for $\delta^{34} S_{\mathrm{PY}}($ s.d. $= \pm 0.3 \%$ ) to compare with SIMS results. Pyrite extraction followed the chromium reduction method of ref. 66 . Sulfur isotopic results are expressed in the standard $\delta$ notation as \%o deviation from VCDT.

\section{References}

1. Cai, Y., Schiffbauer, J. D., Hua, H. \& Xiao, S. Preservational modes in the Ediacaran Gaojiashan Lagerstätte: pyritization, aluminosilicification, and carbonaceous compression. Palaeogeogr. Palaeoclimatol. Palaeoecol. 326-328, 109-117 (2012).

2. Briggs, D. E. G. The role of decay and mineralization in the preservation of softbodied fossils. Annu. Rev. Earth Planet. Sci. 31, 275-301 (2003).

3. Seilacher, A. Begriff and bedeutung der Fossil-Lagerstätten. N. Jb. Geol. Palaontol. Abh. 1970, 34-39 (1970).

4. Allison, P. A. \& Briggs, D. E. G. Exceptional fossils record: distribution of softtissue preservation through the Phanerozoic. Geology 21, 527-530 (1993).

5. Schiffbauer, J. D. \& Laflamme, M. Lagerstätten through time: a collection of exceptional preservational pathways from the terminal Proterozoic through today. Palaios 27, 275-278 (2012).

6. Butterfield, N. J. Exceptional fossil preservation and the Cambrian Explosion. Integr. Comp. Biol. 43, 166-177 (2003).

7. Xiao, S. \& Schiffbauer, J. D. in From Fossils to Astrobiology: Cellular Origin, Life in Extreme Habitats and Astrobiology (eds Seckbach, J. \& Walsh, M.) 89-118 (Springer, 2009).

8. Canfield, D. E. \& Raiswell, R. in Taphonomy; releasing the data locked in the fossil record (eds Allison, Peter A. \& Briggs, Derek E. G.) 337-387 (Plenum Press, 1991).

9. Briggs, D. E. G., Raiswell, R., Bottrell, S. H., Hatfield, D. \& Bartels, C. Controls on the pyritization of exceptionally preserved fossils: an analysis of the Lower Devonian Hunsrueck Slate of Germany. Am. J. Sci. 296, 633-663 (1996).

10. Cai, Y. \& Hua, H. Pyritization in the Gaojiashan Biota. Chinese Sci. Bull. 52, 645-650 (2007).

11. Cai, Y., Hua, H., Xiao, S., Schiffbauer, J. D. \& Li, P. Biostratinomy of the late Ediacaran pyritized Gaojiashan Lagerstätte from southern Shaanxi, South China: importance of event deposits. Palaios 25, 487-506 (2010).

12. Gabbott, S. E., Hou, X. G., Norry, M. J. \& Siveter, D. J. Preservation of Early Cambrian animals of the Chengjiang biota. Geology 32, 901-904 (2004).
13. Farrell, Ú. C., Briggs, D. E. G., Hammarlund, E. H., Sperling, E. A. \& Gaines, R. R. Paleoredox and pyritization of soft-bodied fossils in the Ordovician Frankfort Shale of New York. Am. J. Sci. 313, 452-489 (2013).

14. Raiswell, R. et al. Turbidite depositional influences on the diagenesis of Beecher's Trilobite Bed and the Hunsruck Slate; sites of soft tissue pyritization. Am. J. Sci. 308, 105-129 (2008).

15. Gaines, R. R. et al. Burgess shale - type biotas were not entirely burrowed away. Geology 40, 283-286 (2012).

16. Orr, P. J., Briggs, D. E. G. \& Kearns, S. L. Cambrian Burgess Shale animals replicated in clay minerals. Science 281, 1173-1175 (1998).

17. Petrovich, R. Mechanisms of fossilization of the soft-bodied and lightly armored faunas of the Burgess Shale and of some other classical localities. Am. J. Sci. 301, 683-726 (2001).

18. Gaines, R. R. et al. Mechanism for Burgess Shale-type preservation. Proc. Natl Acad. Sci. USA 109, 5180-5184 (2012).

19. Butterfield, N. J. Does cement-induced sulfate limitation account for Burgess Shale-type preservation? Proc. Natl Acad. Sci. USA 109, E1901 (2012).

20. Xiao, S., Yuan, X., Steiner, M. \& Knoll, A. H. Macroscopic carbonaceous compressions in a terminal Proterozoic shale: a systematic reassessment of the Miaohe biota, South China. J. Paleontol. 76, 345-374 (2002).

21. Anderson, E. P., Schiffbauer, J. D. \& Xiao, S. Taphonomic study of organicwalled microfossils confirms the importance of clay minerals and pyrite in Burgess Shale-type preservation. Geology 39, 643-646 (2011).

22. Gaines, R. R., Briggs, D. E. G. \& Yuanlong, Z. Cambrian Burgess Shale-type deposits share a common mode of fossilization. Geology 36, 755-758 (2008).

23. Van Roy, P. et al. Ordovician faunas of Burgess Shale type. Nature 465, 215-218 (2010).

24. Lin, J.-P. \& Briggs, D. E. G. Burgess Shale-type preservation: a comparison of Naraoiids (Arthropoda) from three Cambrian localities. Palaios 25, 463-467 (2010).

25. Fike, D. A. \& Grotzinger, J. P. A paired sulfate-pyrite $\delta^{34}$ S approach to understanding the evolution of the Ediacaran-Cambrian sulfur cycle. Geochim Cosmochim. Acta 72, 2636-2648 (2008).

26. Lin, S., Zhang, Y., Zhang, L., Tao, X. \& Wang, M. Body and trace fossils of metazoa and algal macrofossils from the upper Sinian Gaojiashan Formation in southern Shaanxi. Geol. Shaanxi 4, 9-17 (1986).

27. Farrell, Ú. C., Martin, M. J., Hagadorn, J. W., Whiteley, T. \& Briggs, D. E. G. Beyond Beecher's Trilobite Bed: widespread pyritization of soft tissues in the Late Ordovician Taconic foreland basin. Geology 37, 907-910 (2009).

28. Cai, Y., Schiffbauer, J. D., Hua, H. \& Xiao, S. Morphology and paleoecology of the late Ediacaran tubular fossil Conotubus hemiannulatus from the Gaojiashan Lagerstätte of southern Shaanxi Province, South China. Precambrian Res. 191, 46-57 (2011).

29. Bartels, C., Briggs, D. E. G. \& Brassel, G. The Fossils of the Hunsrück Slate: Marine Life in the Devonian 309 (Cambridge Univ. Press, 1998).

30. Bergström, J., Briggs, D. E. G., Dahl, E., Rolfe, W. D. I. \& Stürmer, W. Nahecaris stuertzi, a phyllocarid crustacean from the Lower Devonian Hunsrück Slate. Paläontologische Zeitschrift 61, 273-298 (1987).

31. Raiswell, R., Whaler, K., Dean, S., Coleman, M. L. \& Briggs, D. E. G. A simple three-dimensional model of diffusion-with-precipitation applied to localised pyrite formation in framboids, fossils and detrital iron minerals. Mar. Geol. 113, 89-100 (1993).

32. Xiao, S., Schiffbauer, J. D., McFadden, K. A. \& Hunter, J. Petrographic and SIMS pyrite sulfur isotope analyses of Ediacaran chert nodules: implications for microbial processes in pyrite rim formation, silicification, and exceptional fossil preservation. Earth Planet. Sci. Lett. 297, 481-495 (2010).

33. Berner, R. A. Sedimentary pyrite formation: an update. Geochim. Cosmochim. Acta 48, 605-615 (1984).

34. Wallace, A. F., De Yoreo, J. J. \& Dove, P. M. Kinetics of silica nucleation on carboxyl- and amine-terminated surfaces: insights for biomineralization. J. Am. Chem. Soc. 131, 5244-5250 (2009).

35. Giuffre, A. J., Hamm, L. M., Han, N., De Yoreo, J. J. \& Dove, P. M. Polysaccharide chemistry regulates kinetics of calcite nucleation through competition of interfacial energies. Proc. Natl Acad. Sci. USA 110, 9261-9266 (2013).

36. Wood, T. L. \& Garrels, R. M. Thermodynamic Values at Low Temperature for Natural Inorganic Materials (Oxford Univ. Press, 1987).

37. Boudreau, B. P. \& Canfield, D. E. A provisional diagenetic model for $\mathrm{pH}$ in anoxic porewaters. J. Mar. Res. 46, 429-455 (1988).

38. Middelburg, J. J. A simple rate model for organic matter decomposition in marine sediments. Geochim. Cosmochim. Acta 53, 3581-3595 (1989).

39. Canfield, D. E. \& Raiswell, R. in Taphonomy: Releasing the Data Locked in the Fossil Record, Volume 9 of Topics in Geobiology (eds Allison, P. A. \& Briggs, D. E. G.) 411-453 (Plenum Press, 1991).

40. Zhang, F., Yan, C., Teng, H., Roden, E. E. \& Xu, H. In situ AFM observations of $\mathrm{Ca}-\mathrm{Mg}$ carbonate crystallization catalyzed by dissolved sulfide: Implications for sedimentary dolomite formation. Geochim. Cosmochim. Acta 105, 44-55 (2013). 
41. Braissant, O. et al. Exopolymeric substances of sulfate-reducing bacteria: Interactions with calcium at alkaline $\mathrm{pH}$ and implication for formation of carbonate minerals. Geobiology 5, 401-411 (2007).

42. Habicht, K. S. \& Canfield, D. E. Isotope fractionation by sulfatereducing natural populations and the isotopic composition of sulfide in marine sediments. Geology 29, 555-558 (2001).

43. Li, C. et al. A stratified redox model for the Ediacaran ocean. Science 328, 80-83 (2010).

44. Raiswell, R. \& Berner, R. A. Pyrite and organic matter in Phanerozoic normal marine shales. Geochim. Cosmochim. Acta 50, 1967-1976 (1986).

45. Canfield, D. E., Raiswell, R. \& Bottrell, S. H. The reactivity of sedimentary iron minerals toward sulfide. Am. J. Sci. 292, 659-683 (1992).

46. Berner, R. A. A new geochemical classification of sedimentary environments. J. Sediment. Petrol. 51, 359-365 (1981).

47. Rickard, D. \& Luther, III G. W. Chemistry of iron sulfides. Chem. Rev. 107, 514-562 (2007).

48. Konhauser, K. O. Introduction to Geomicrobiology (Blackwell Publishing, 2007).

49. Allison, P. A. \& Briggs, D. E. G. Burgess Shale biotas; burrowed away? Lethaia 26, 184-185 (1993).

50. Orr, P. J., Benton, M. J. \& Briggs, D. E. G. Post-Cambrian closure of the deep-water slope-basin taphonomic window. Geology 31, 769-772 (2003).

51. Condon, D. et al. U-Pb ages from the Neoproterozoic Doushantuo Formation, China. Science 308, 95-98 (2005).

52. Bowring, S. A. et al. Geochronologic constraints on the chronostratgraphic framework of the Neoproterozoic Huqf Supergroup, Sultanate of Oman. Am. J. Sci. 307, 1097-1145 (2007).

53. Cai, Y., Hua, H., Schiffbauer, J. D., Sun, B. \& Xiao, S. Tube growth patterns and microbial mat-related lifestyles in the Ediacaran fossil Cloudina, Gaojiashan Lagerstätte, South China. Gondwana Res. 25, 1008-1018 (2014).

54. Chen, Z., Bengtson, S., Zhou, C., Hua, H. \& Yue, Z. Tube structure and original composition of Sinotubulites: Shelly fossils from the late Neoproterozoic in southern Shaanxi, China. Lethaia 41, 37-45 (2008).

55. Hua, H., Chen, Z. \& Yuan, X. The advent of mineralized skeletons in Neoproterozoic Metazoa: new fossil evidence from the Gaojiashan Fauna. Geol. J. 42, 263-279 (2007).

56. Hua, H., Chen, Z., Yuan, X., Xiao, S. \& Cai, Y. The earliest Foraminifera from southern Shaanxi, China. Sci. China D 53, 1756-1764 (2010).

57. Hua, H., Chen, Z., Yuan, X., Zhang, L. \& Xiao, S. Skeletogenesis and asexual reproduction in the earliest biomineralizing animal Cloudina. Geology 33, 277-280 (2005).

58. Hua, H., Pratt, B. R. \& Zhang, L. Borings in Cloudina shells: complex predatorprey dynamics in the terminal Neoproterozoic. Palaios 18, 454-459 (2003).

59. Meyer, M., Schiffbauer, J. D., Xiao, S., Cai, Y. \& Hua, H. Taphonomy of the late Ediacaran enigmatic ribbon-like fossil Shaanxilithes. Palaios 27, 354-372 (2012).

60. Zhang, P., Hua, H. \& Liu, W. Isotopic and REE evidence for the paleoenvironmental evolution of the late Ediacaran Dengying Section, Ningqiang of Shaanxi Province, China. Precambrian. Res. 242, 96-111 (2014).

61. Ault, W. V. \& Jensen, M. L. in Biogeochemistry of Sulfur Isotopes: National Science Foundation Symposium Proceedings. (ed. Jensen, M. L.) 16-29 (Yale Univ. Press, 1962).
62. Crowe, D. E. \& Vaughan, R. G. Characterization and use of isotopically homogeneous standards for in situ laser microprobe analysis of ${ }^{34} \mathrm{~S} /{ }^{32} \mathrm{~S}$ ratios. Am. Mineral. 81, 187-193 (1996).

63. Kohn, M. J., Riciputi, L. R., Stakes, D. \& Orange, D. L. Sulfur isotope variability in biogenic pyrites: reflections of heterogeneous bacterial colonization? Am. Mineral. 83, 1454-1468 (1998).

64. Wotte, T., Shields-Zhou, G. A. \& Strauss, H. Carbonate-associated sulfate: experimental comparisons of common extraction methods and recommendations toward a standard analytical protocol. Chem. Geol. 326, 132-144 (2012).

65. Bao, H. Purifying barite for oxygen isotope measurement by dissolution and reprecipitation in a chelating solution. Anal. Chem. 78, 304-309 (2006).

66. Canfield, D. E., Raiswell, R., Westrich, J. T., Reaves, C. M. \& Berner, R. A The use of chromium reduction in the analysis of reduced inorganic sulfur in sediments and shale. Chem. Geol. 54, 149-155 (1986).

67. Froelich, P. N. Early oxidation of organic matter in pelagic sediments of the eastern equitorial Atlantic: Suboxic diagenesis. Geochim. Cosmochim. Acta 43, 1075-1090 (1979).

\section{Acknowledgements}

This research was supported by funding through NASA Exobiology and Evolutionary Biology Program, NASA Astrobiology Institute (N07-5489), National Science Foundation (EAR-0824890, EAR095800, EAR1124062), Chinese Academy of Sciences, National Natural Science Foundation of China (41202006; 41030209; 41272011), Chinese Ministry of Science and Technology, Virginia Tech Institute for Critical Technology and Applied Sciences and China Postdoctoral Science Foundation (2013M531410). We would like to thank K.L. Shelton and J.W. Huntley for insightful discussion.

\section{Author contributions}

J.D.S. designed the research with input from S.X. and Y.C. S.X. supervised the research J.D.S, S.X., Y.C. and H.H. performed the fieldwork. Sample preparation was performed by J.D.S. and Y.C., SEM and EDS analysis was performed by J.D.S., SIMS analysis was performed by J.D.S. and J.H., ultraviolet and XRD analysis was performed by H.X., IRMS analysis performed by Y.C., Y.P. and A.J.K. and geochemical data analysis was performed by J.D.S., S.X. and A.F.W. J.D.S., with significant input from all of the authors, wrote the paper.

\section{Additional information}

Supplementary Information accompanies this paper at http://www.nature.com/ naturecommunications

Competing financial interests: The authors declare no competing financial interests

Reprints and permission information is available online at http://npg.nature.com/ reprintsandpermissions/

How to cite this article: Schiffbauer, J. D. et al. A unifying model for NeoproterozoicPalaeozoic exceptional fossil preservation through pyritization and carbonaceous compression. Nat. Commun. 5:5754 doi: 10.1038/ncomms6754 (2014). 